\title{
Short-term infection of striped bass Morone saxatilis with Mycobacterium marinum
}

\author{
Soo Jin Jeon ${ }^{1}$, Lonnie C. Gonsalves ${ }^{2,3}$, John M. Jacobs ${ }^{3}$, Matt Rhodes ${ }^{3}$, \\ Jimmy Councilman ${ }^{3}$, Ana Baya ${ }^{3}$, Eric B. May ${ }^{2}$, Mark D. Fast ${ }^{1,4, *}$ \\ ${ }^{1}$ School of Marine and Atmospheric Sciences, Stony Brook University, Stony Brook, New York 11794-5000, USA \\ ${ }^{2}$ NOAA Living Marine Resources Cooperative Science Center, Department of Natural Sciences, University of Maryland \\ Eastern Shore, Princess Anne, Maryland 21853, USA \\ ${ }^{3}$ NOAA National Ocean Service (NOS), Center for Coastal Environmental Health and Biomolecular Research (CCEHBR)/ \\ Cooperative Oxford Laboratory, Oxford, Maryland 21654, USA \\ ${ }^{4}$ Department of Pathology and Microbiology, Atlantic Veterinary College, University of Prince Edward Island, \\ Charlottetown, Prince Edward Island, C1A 4P3, Canada
}

\begin{abstract}
Striped bass Morone saxatilis were studied in order to characterize their immune responses over the short term following challenge with Mycobacterium marinum. The expression of immunity-related genes ( $I L-1 \beta, T N F-\alpha, N r a m p$ and $T G F-\beta)$ quickly increased following infection with M. marinum, but these genes were subsequently down-regulated despite the fact that bacterial counts remained high. The number of monocytes and neutrophils also initially increased at $1 \mathrm{~d}$ postinfection. This confirms the importance of these types of cells in initial inflammation and mycobacterial infection in striped bass. The phagocytic index of splenic leukocytes over these same time frames did not change significantly following infection. The discrete window in which inflammatory mechanisms were stimulated in striped bass may be related to the intracellular nature of this pathogen.
\end{abstract}

KEY WORDS: Mycobacteriosis - Striped bass - Gene expression · Interleukin-1 $\beta$ IL-1 $\cdot$ Tumor necrosis factor- $\alpha \cdot T N F-\alpha \cdot$ Natural resistance-associated macrophage protein $\cdot$ Nramp $\cdot$ Transforming growth factor- $\beta \cdot T G F-\beta$

\section{INTRODUCTION}

Striped bass Morone saxatilis are naturally susceptible to mycobacteriosis caused by Mycobacterium spp. (Hecker et al. 2001, Gauthier \& Rhodes 2009, Jacobs et al. 2009b). Recently, several surveys have shown that striped bass exhibit a high prevalence $(>50 \%)$ of age- and sex-dependent mycobacteriosis in the Chesapeake Bay (Vogelbein et al. 1999, Cardinal 2001, Overton et al. 2003). The prevalence of mycobacteriosis in striped bass from the Chesapeake Bay appears to increase from age 1 to $5 \mathrm{yr}$ old, and above these ages is maintained at higher prevalency in males as compared to females (Gauthier \& Rhodes 2009). Due to the chronic, progressive nature of the disease, mortality is of great concern and a commonly observed endpoint in aquaculture (Nigrelli \& Vogel 1963, Hedrick et al. 1987, Bruno et al. 1998, Gauthier et al. 2008).

Mycobacterium marinum is an important fish pathogen that was first identified by Aronson (1926). It causes chronic and systemic disease with granulomatous lesions, similar to human tuberculosis. It can affect all organs, but granulomas are observed mainly in spleen, kidney and liver tissue (Nigrelli \& Vogel 1963). This fish pathogen has been used as a model for tuber- 
culosis in humans due to its relatively fast growth $(\sim 4 \mathrm{~h}$ generation time) and its genetic similarity to $M$. tuberculosis (Tonjum et al. 1998, Cosma et al. 2003). Several aquatic animal models have been used in the past to study immune responses to infection with $M$. marinum, including goldfish Carassius auratus, zebrafish Danio rerio, leopard frog Rana pipiens and medaka Oryzias latipes (Ramakrishnan et al. 1997, Talaat et al. 1998, Decostere et al. 2004, Broussard \& Ennis 2007).

Due to the chronic nature of disease caused by $\mathrm{My}$ cobacterium marinum, previous studies have concentrated on host responses over the long term, looking at the formation and persistence of granulomas in host organs. Only the work of Burge et al. (2004) and Harms et al. (2003) have addressed the early-phase response, and in those cases only in vitro. Here, we investigate the initiation of immune responses in the striped bass Morone saxatilis to an in vivo challenge from $M$. marinum using markers for inflammation (interleukin-1 $\beta[I L-1 \beta]$, tumor necrosis factor- $\alpha[I N F-\alpha]$, transforming growth factor- $\beta$ [IGF- $\beta]$ expression) and bacterial killing mechanisms (natural resistance-associated macrophage protein [Nramp] expression, phagocytic index).

\section{MATERIALS AND METHODS}

Experimental fish and maintenance. One-year-old striped bass Morone saxatilis, Choptank River, Maryland strain, were obtained from Delmarva Aquatics. These fish were transported to the Cooperative Oxford Laboratory (COL) to allow for fish and system acclimation. A total of 100 fish (mean weight $=50 \pm 5 \mathrm{~g}$ ) were randomly stocked in sixteen $568 \mathrm{l}$ circular tanks at 12 to 13 fish per tank and allowed to acclimatize for 1 mo. Experimental conditions were set as: photoperiod $12 \mathrm{~h}$ light: $12 \mathrm{~h}$ dark, $\mathrm{pH}$ 8.2, salinity $10 \mathrm{ppt}$, temperature $21^{\circ} \mathrm{C}$. Water quality $\left(\mathrm{dO}, \mathrm{NH}_{3}, \mathrm{NH}_{4}, \mathrm{NO}_{2}\right)$ remained in a healthy range for the species (Harrell et al. 1990) through daily monitoring of all systems and water exchange $\left(10 \%\right.$ volume $\left.\mathrm{wk}^{-1}\right)$.

Mycobacterium marinum isolate and inoculation. The $M$. marinum isolate (FL03-23) was passed through six $30 \mathrm{~g}$ striped bass once, and re-isolated from spleen homogenates, before the initiation of the experiments. The inoculation procedures used were identical to those employed by Jacobs et al. (2009a). All fish were removed from their tanks, anesthetized in MS-222, weighed and measured before inoculation. Fish were inoculated intraperitoneally (i.p.) with $100 \mu \mathrm{l}$ of either diluted M. marinum suspension (treatment) or sterile Butterfield's phosphate-buffered saline (BPBS) (control).

Tissue sampling. Fish ( $\mathrm{n}=8$ in each group) were sacrificed prior to infection (time 0 ) and at 1, 3, 7 and $14 \mathrm{~d}$ post-infection (dpi). Head kidney was collected for RNA analysis, preserved in RNAlater ${ }^{\mathrm{TM}}$ (Ambion) and frozen at $-80^{\circ} \mathrm{C}$; spleen was taken for phagocytosis assay (fluorescein isothiocyanate [FITC] yeast) and bacterial counts. Spleens for bacterial counts were collected in sterile whirl packs and stored at $-20^{\circ} \mathrm{C}$, whereas spleens for phagocytosis assay were used fresh. Blood was also extracted for leukocyte counts at each sampling point.

Bacterial count. Prior to plating, each spleen portion was weighed and homogenized inside a whirl pack using a pestle. Spleen slurries were further homogenized in $2 \mathrm{ml}$ phosphate-buffered saline solution (PBS) by placing the whirl packs inside a stomacher for 2 min. Spleen homogenate $(200 \mu \mathrm{l})$ was plated onto Middlebrook agar plates without dilution and allowed to grow at ambient temperature for 2 to $4 \mathrm{wk}$ before counting the number of colony-forming units (CFU). Each spleen sample was plated in duplicate, and average values for duplicate plates were used for analysis.

RNA extraction. RNA was extracted from fish tissues using TRIzol ${ }^{\circledR}$ LS Reagent (Invitrogen) according to the manufacturer's instructions, with the following exceptions. Kidney, spleen and liver tissue were immediately added to TRIzol ${ }^{\circledR}$ LS Reagent $(0.75 \mathrm{ml})$ and macerated manually with a micro-tube pestle. The RNA pellet isolated using this procedure was dissolved in $40 \mu \mathrm{l}$ molecular biology grade water (MBGW, Sigma-Aldrich) before storage at $-80^{\circ} \mathrm{C}$. Total RNA concentration was measured using the NanoDrop1000 Spectrophotometer (v3.2.1, Thermo Scientific). The RNA extracted was then reverse transcribed to obtain cDNA using Superscript III reverse transcriptase and RNAse OUT following the manufacturer's protocol (Invitrogen). The reverse transcription (RT) reaction was performed in a $20 \mu$ l mixture containing $1.5 \mu \mathrm{g}$ of total mRNA, $2 \mu \mathrm{l}$ of RT enzyme mix (dNTPs, $\mathrm{MgCl}$, random hexamers and oligo dTs) and $10 \mu \mathrm{l}$ of RT reaction mix.

Quantitative real-time PCR (qPCR). qPCR was performed on a subset of 4 genes, including important cytokine genes (IL-1 $\beta, T N F-\alpha$ and TGF- $\beta$ ) and Nramp (Table 1). The elongation factor-1 $\alpha(E F-1 \alpha)$ gene was used as the internal control/housekeeping gene due to its stability in striped bass across tissues during immunological stimulation (S. J. Jeon \& M. D. Fast pers. obs.). Degenerate primers were designed for striped bass $I L-1 \beta$ and $T N F-\alpha$ based on consensus sequences of 14 teleost species: for $I L-1 \beta$ (Danio rerio: NM_212844, Cyprinus carpio: AJ245635, Oncorhynchus mykiss: AJ223954, Dicentrarchus labrax: AJ311925, Diplodus puntazzo: AJ459238, Latris lineata: FJ532282, Lateolabrax japonicus: AY383480) and for TNF- $\alpha$ cDNAs (Salmo salar: NM_001123617, Takifugu rubripes: NM_001037985, Danio rerio: AB183467, 
Oplegnathus fasciatus: FJ623187, Epinephelus awoara: AY667275, Lateolabrax japonicus: AY376595, Dicentrarchus labrax: DQ070246) (Table 1). Primers for qPCR were constructed using Primer3 software (Table 1). qPCR assays were performed using an Eppendorf Mastercycler ep realplex 2.0 and SYBR Green kits (Invitrogen). The SYBR Green mastermix kit was used as recommended by the manufacturer with the following exceptions. The primers used are identified above. SYBR Green $(25 \mu \mathrm{l})$ was added to template cDNA $(2 \mu \mathrm{l}), \operatorname{ROX}(1 \mu \mathrm{l}), \mathrm{MBGW}$ water $(20 \mu \mathrm{l})$ and $10 \mu \mathrm{M}$ of forward and reverse primers $(2 \mu \mathrm{l})$ giving a total volume of $50 \mu \mathrm{l}$ prior to dividing into separate wells for duplication of readings. The threshold cycling $\left(C_{\mathrm{T}}\right)$ conditions were as follows: denaturation $10 \mathrm{~min}$ at $95^{\circ} \mathrm{C}$, then 40 cycles of $15 \mathrm{~s}$ at $95^{\circ} \mathrm{C}$ and $30 \mathrm{~s}$ at $58^{\circ} \mathrm{C}$ and finally a temperature increase from 60 to $95^{\circ} \mathrm{C}$ for the melting curve step. The $\Delta C_{\mathrm{T}}$ method $\left(\Delta C_{\mathrm{T}}=C_{\mathrm{T}}\right.$ of the target gene $-C_{\mathrm{T}}$ of the housekeeping gene) was used for each fish. Finally, the fold change relative to time 0 was calculated using the $2^{-\Delta \Delta C_{\mathrm{T}}}$ method (Livak \& Schmittgen 2001).

$E F-1 \alpha$ was chosen as the housekeeping gene for the present study on the basis of previous work in striped bass Morone saxatilis and other species (Fast et al. 2007, M. D. Fast pers. obs.) and it showed no significant change in its expression, regardless of treatment or sampling time (mean $C_{\mathrm{T}}$ values for $E F-1 \alpha$ were 23 to 24 for all fish over the course of the experiment). The use of the $2^{-\Delta \Delta C_{\mathrm{T}}}$ method herein was also valid due to efficiencies for target genes and housekeeping genes being maintained within the 'gold standard range' of $10 \%$ of one another (all efficiencies fell within the range 96 to $102 \%$ ).
Differential leukocyte population determination. Blood smear slides were made from each of 5 fish (control and treatment) at each sampling time. Smears were allowed to dry at room temperature for 1 to $2 \mathrm{~h}$ prior to fixation and staining; we used a Wright's Giemsa (WG) staining method. A total of 200 leukocytes were counted on each slide to determine the differential leukocyte percentages using a Nikon ECLIPSE E200 light microscope under oil immersion at 1000x magnification.

Phagocytosis assay. Following retrieval, each spleen portion was placed immediately in cRPMI (RPMI solution with phenol red and L-glutamine supplemented with $10 \%$ fetal bovine serum, 1\% EDTA, and $100 \mathrm{nU}$ penicillin and streptomycin) and held on ice. Leukocytes were isolated on the same day of extraction by teasing the spleen portions through a $100 \mu \mathrm{l}$ nylon mesh strainer. Following centrifugation at $400 \times g$ at $4^{\circ} \mathrm{C}$ for $5 \mathrm{~min}$, the cell pellet was resuspended in $5 \mathrm{ml}$ CRPMI. Macrophages (90.1\% confirmed through WG and microscopy) were isolated by layering the cell suspension over a 40 and $51 \%$ Percoll gradient (Polonio et al. 2000). Cell counts and cell viability were calculated using a hemocytometer and trypan blue staining. Each cell suspension was adjusted to $1 \times 10^{7}$ cells ml-1 .

The phagocytosis assay was performed using a 96well plate format; $100 \mu \mathrm{l}$ of each cell suspension $(1 \times$ $10^{6}$ cells) were plated in triplicate on 96-well tissueculture plates. FITC-labeled yeast $(100 \mu \mathrm{l})$ was added to each well together with an additional $25 \mu$ of CRPMI. The plates were incubated for $2 \mathrm{~h}$ at $27^{\circ} \mathrm{C}$ under $5 \% \mathrm{CO}_{2}$. Following incubation, $25 \mu \mathrm{l}$ of ice-cold $0.4 \%$ trypan blue were added to each well in order to quench extracellular fluorescence. Absorbance was then read at $495 \mathrm{~nm}$. In order to quantify the amount of

Table 1. Sequences of the oligonucleotide primers used for sequencing and quantitive real-time PCR for striped bass Morone saxatilis immunity genes. F: forward; R: reverse; deg: degenerate; $\mathrm{Y}=\mathrm{C}$ or $\mathrm{T}, \mathrm{R}=\mathrm{G}$ or $\mathrm{A}, \mathrm{D}=\mathrm{G}$ or $\mathrm{A}$ or $\mathrm{T}, \mathrm{V}=\mathrm{G}$ or $\mathrm{A}$ or $\mathrm{C}$, $\mathrm{W}=\mathrm{A}$ or $\mathrm{T}, \mathrm{B}=\mathrm{G}$ or $\mathrm{T}$ or $\mathrm{C}, \mathrm{H}=\mathrm{A}$ or $\mathrm{T}$ or $\mathrm{C}$

\begin{tabular}{|c|c|c|}
\hline Primer name & $5^{\prime}$ to $3^{\prime}$ sequence & Product length (bp) \\
\hline IL-1 $\beta-F(d e g)$ & CYG TGR CTC TGD RCA TCA AGG & 146 \\
\hline IL-1 $\beta-R(\operatorname{deg})$ & GAA GAG VAA TCG YRC CAT GTC GCT & \\
\hline TNF- $\alpha-F($ deg) & TAC TTH GTC TAC WSC CAG GCG TCG TTC & 238 \\
\hline TNF- $\alpha-R(\operatorname{deg})$ & GCT GRA ACA CBG CDC CHA GAT ARA TGG & \\
\hline MsIL-1 $\beta-R T-F$ & CAG ACT GGC TTT GTC CAC TG & 77 \\
\hline MsIL-1 $\beta-R T-R$ & AGT CCT GCT GAT TTG ATC TAC C & \\
\hline MsTNF- $\alpha-R T-F$ & AAC GAT GGT GAA GAG GAA AG & 80 \\
\hline MsTNF- $\alpha-R T-R$ & CCT ATG GAG TCT GAG TAG CG & \\
\hline MsNramp-RT-F & TAT TGT GAT GTG CGT GCA GC & 85 \\
\hline MsNramp-RT-R & AGG CTC TGA GGA TCA AGC TG & \\
\hline MsTGF- $\beta-R T-F$ & ATG GTT AAG AAA AAG CGC ATT GAA & 80 \\
\hline MsTGF- $\beta-R T-R$ & TCC GGC TCA GGC TCT TTG & \\
\hline $\mathrm{EF}-1 \alpha-\mathrm{F}$ & CTT GAC GGA CAC GTT CTT GA & 151 \\
\hline$E F-1 \alpha-R$ & GTG GAG ACC GGT GTC CTG AA & \\
\hline
\end{tabular}


yeast engulfed, standard curves using FITC-yeast were developed during each assay run $\left(R^{2}>0.94\right)$. Absorbance readings caused by extracellular FITCyeast not quenched by trypan blue were calculated by comparing values generated from wells with FITCyeast to wells with FITC-yeast + trypan blue. The percentage difference in these values was subtracted from the total absorbance measured in each sample well. Each phagocytosis assay was performed $24 \mathrm{~h}$ post-sacrifice of the fish.

Statistical analysis. Statistical analyses were performed using SigmaStat for Windows Version 3.0 (SPSS). All values shown are means of individuals for each sampling time \pm SEM. The statistical significance of differences in gene expression was assessed on expression changes relative to housekeeping gene expression, and gene expression of saline-injected control using 1-way ANOVA followed by the Tukey test. A value of $\mathrm{p}<0.05$ was considered significant.

\section{RESULTS}

Bacterial counts were assessed from the spleens of striped bass Morone saxatilis injected with Mycobacterium marinum over a period of $14 \mathrm{~d}$. Counts in the spleens of the treatment group began to increase at $3 \mathrm{dpi}$ and had the highest density at $14 \mathrm{dpi}$, while no bacteria were observed in controls throughout the experiment (Fig. 1).

Expression of $I L-1 \beta$ did not differ between the control and treatment groups at $1 \mathrm{dpi}$. At 3 and $7 \mathrm{dpi}$, however, expression in head kidneys of infected fish was significantly higher $(\mathrm{p}<0.01)$ when compared to control fish (Fig. 2). After 7 dpi, a dramatic change in

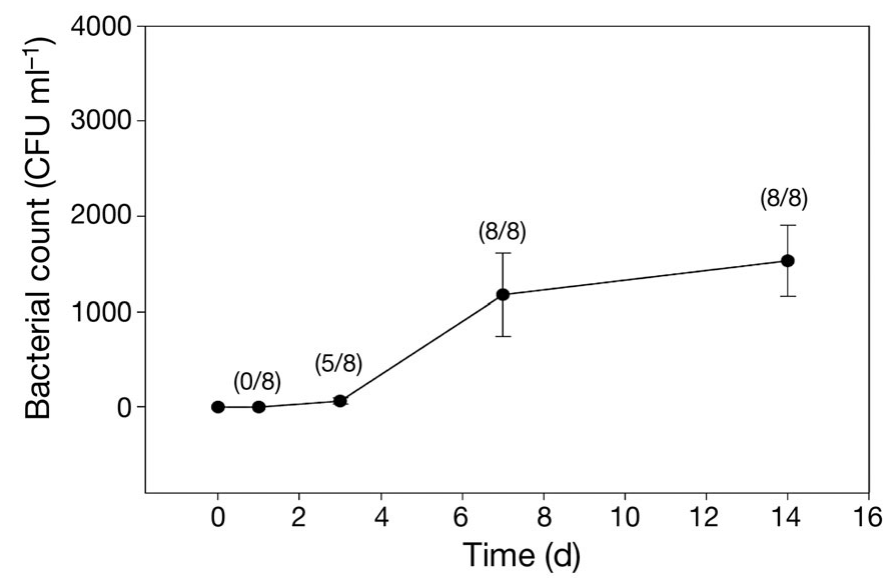

Fig. 1. Mycobacterium marinum in Morone saxatilis. Mean $( \pm$ SEM) bacterial count in striped bass spleens over $14 \mathrm{~d}$. The fish were injected with $10^{4}$ colony-forming units (CFU) $\mathrm{g}^{-1}$ M. marinum. Numbers denote infected fish out of each group (8 fish in each group)

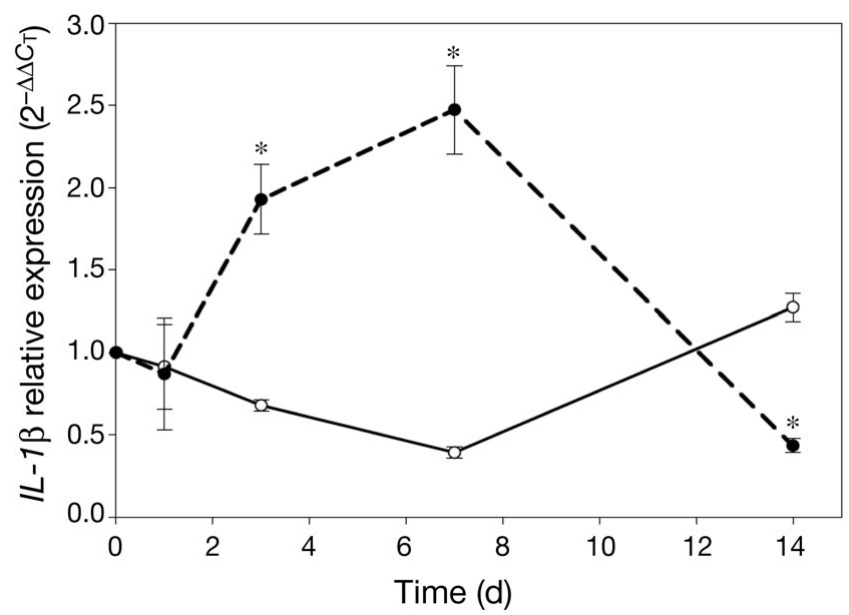

Fig. 2. Time course of mean $( \pm \mathrm{SEM})$ expression of the inter-

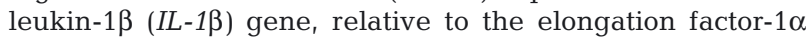
$(E F-1 \alpha)$ gene, in striped bass Morone saxatilis following intraperitoneal injection with phosphate-buffered saline (PBS) (O) or Mycobacterium marinum (๑). *Significantly different expression $(p<0.01)$ in infected fish when compared to PBSinjected (control) fish at these times. $R=2^{-\left[\Delta C_{\mathrm{T}}\left(t_{\mathrm{n}}\right)-\Delta C_{\mathrm{T}}\left(t_{0}\right)\right]}$ where $R$ is the relative expression of the gene of interest, $C_{\mathrm{T}}$ is the cycle threshold, and $\Delta C_{\mathrm{T}}$ is the difference in the $C_{\mathrm{T}}$ value of the gene of interest when compared with EF-1 (reference gene) after normalization

head kidney $I L-1 \beta$ expression in infected fish was observed by $14 \mathrm{dpi}$, with significantly lower expression $(\mathrm{p}<0.01)$ when compared to expression in control fish. Expression of $T N F-\alpha$, similar to $I L-1 \beta$, was

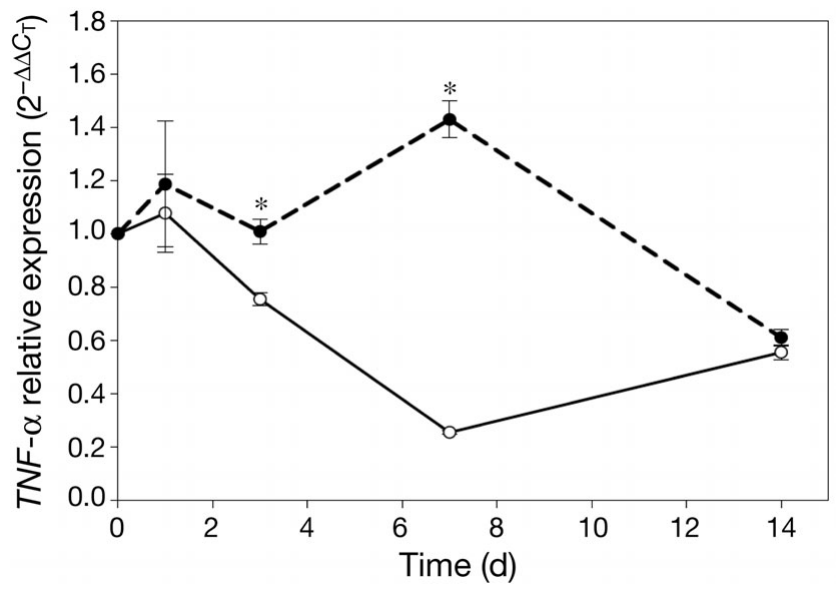

Fig. 3. Time course of mean $( \pm \mathrm{SEM})$ expression of the tumor necrosis factor- $\alpha(T N F-\alpha)$ gene, relative to the elongation factor-1 $\alpha(E F-1 \alpha)$ gene, in striped bass Morone saxatilis following intraperitoneal injection with phosphate-buffered saline (PBS) (O) or Mycobacterium marinum (•). *Significantly higher expression $(\mathrm{p}<0.05)$ in infected fish when compared to PBS-injected (control) fish at these times. $R=$ $2^{-\left[\Delta C_{\mathrm{T}}\left(t_{\mathrm{n}}\right)-\Delta C_{\mathrm{T}}\left(t_{0}\right)\right]}$ where $R$ is the relative expression of the gene of interest, $C_{\mathrm{T}}$ is the cycle threshold, and $\Delta C_{\mathrm{T}}$ is the difference in the $C_{\mathrm{T}}$ value of the gene of interest when compared with $E F-1$ (reference gene) after normalization 
significantly higher $(p<0.05)$ in head kidneys of infected fish when compared to controls at 3 and $7 \mathrm{dpi}$, before returning to control levels at $14 \mathrm{dpi}$ (Fig. 3). However, the level of expression in head kidneys of infected fish at 3 dpi was similar to that seen at time 0 (in the uninjected control). In contrast to $I L-1 \beta$ and TNF- $\alpha, N r a m p$ and TGF- $\beta$ expression were up-regulated at $1 \mathrm{dpi}$; however, the expression was not significantly higher when compared to salineinjected controls (Figs. 4 \& 5). Nramp and TGF- $\beta$ both showed significantly elevated expression $(p<0.05)$ in infected fish head kidneys at 3 and 7 dpi when compared to controls. The increased expression of Nramp and $T G F-\beta$ in infected fish, similar to $I L-1 \beta$ and $T N F-\alpha$, was gone by $14 \mathrm{dpi}$.

Leukocyte populations in the blood also exhibited changes over the course of the experiment. In fish injected with Mycobacterium marinum, the number of monocytes and neutrophils initially increased at $1 \mathrm{dpi}$ (Fig. 6a). The percentage of leukocytes made up of monocytes was highest at $1 \mathrm{dpi}$, while neutrophils were highest at $3 \mathrm{dpi}$. At $7 \mathrm{dpi}$, the increased proportion of these cells in the blood disappeared. In PBSinjected controls, a small increase in neutrophils was observed at $3 \mathrm{dpi}$; however, no obvious changes in cell distribution were found on other days (Fig. 6b).

Despite changes in leukocyte populations in the blood, and inflammatory gene expression in the kidney, little changed in the phagocytic index of splenic leukocytes of striped bass Morone saxatilis (Fig. 7).

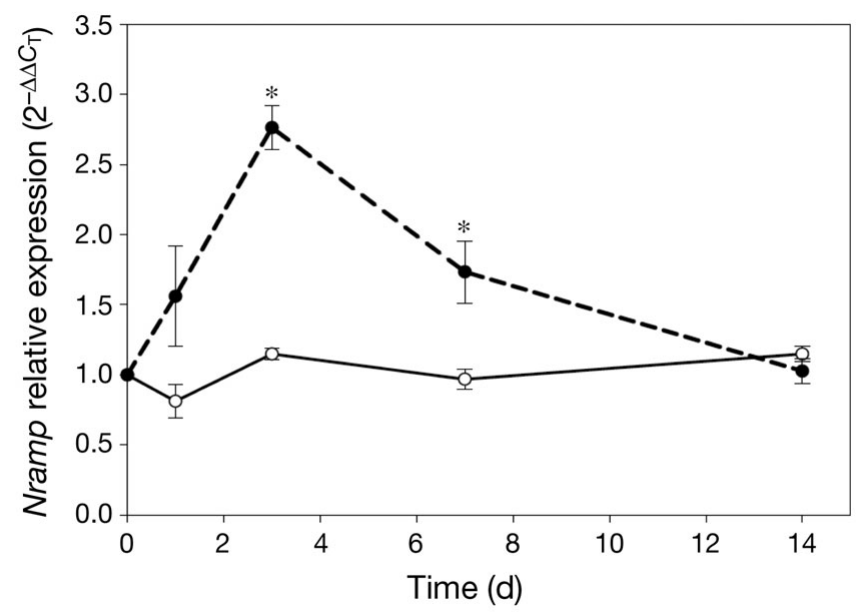

Fig. 4. Time course of mean $( \pm$ SEM) expression of the natural resistance-associated macrophage protein (Nramp) gene, relative to the elongation factor- $1 \alpha(E F-1 \alpha)$ gene, in striped bass Morone saxatilis following intraperitoneal injection with phosphate-buffered saline (PBS) (O) or Mycobacterium marinum (๑). *Significantly higher expression $(\mathrm{p}<0.05)$ in infected fish when compared to PBS-injected (control) fish at these times. $R=2^{-\left[\Delta C_{\mathrm{T}}\left(t_{\mathrm{n}}\right)-\Delta C_{\mathrm{T}}\left(t_{0}\right)\right]}$ where $R$ is the relative expression of the gene of interest, $C_{\mathrm{T}}$ is the cycle threshold, and $\Delta C_{\mathrm{T}}$ is the difference in the $C_{\mathrm{T}}$ value of the gene of interest when compared with EF-1 (reference gene) after normalization

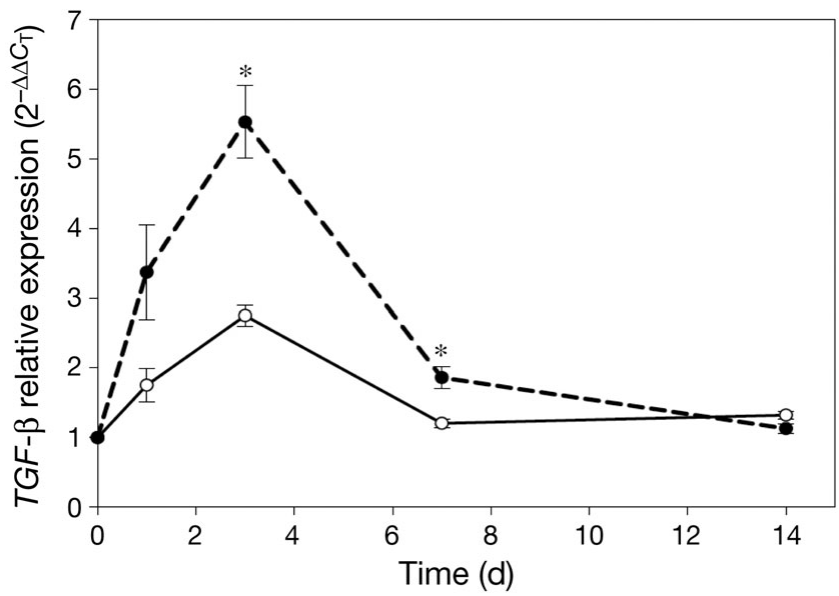

Fig. 5. Time course of mean $( \pm \mathrm{SEM})$ expression of the transforming growth factor- $\beta$ (TGF- $\beta$ ) gene, relative to the elongation factor-1 $\alpha(E F-1 \alpha)$ gene, in striped bass Morone saxatilis following intraperitoneal injection with phosphate-buffered saline (PBS) (O) or Mycobacterium marinum (•). *Significantly higher expression $(p<0.05)$ in infected fish whencompared to PBS-injected (control) fish at these times. $R=$ $2^{-\left[\Delta C_{\mathrm{T}}\left(t_{n}\right)-\Delta C_{\mathrm{T}}\left(t_{0}\right)\right]}$ where $R$ is the relative expression of the gene of interest, $C_{\mathrm{T}}$ is the cycle threshold, and $\Delta C_{\mathrm{T}}$ is the difference in the $C_{\mathrm{T}}$ value of the gene of interest when compared with $E F-1$ (reference gene) after normalization

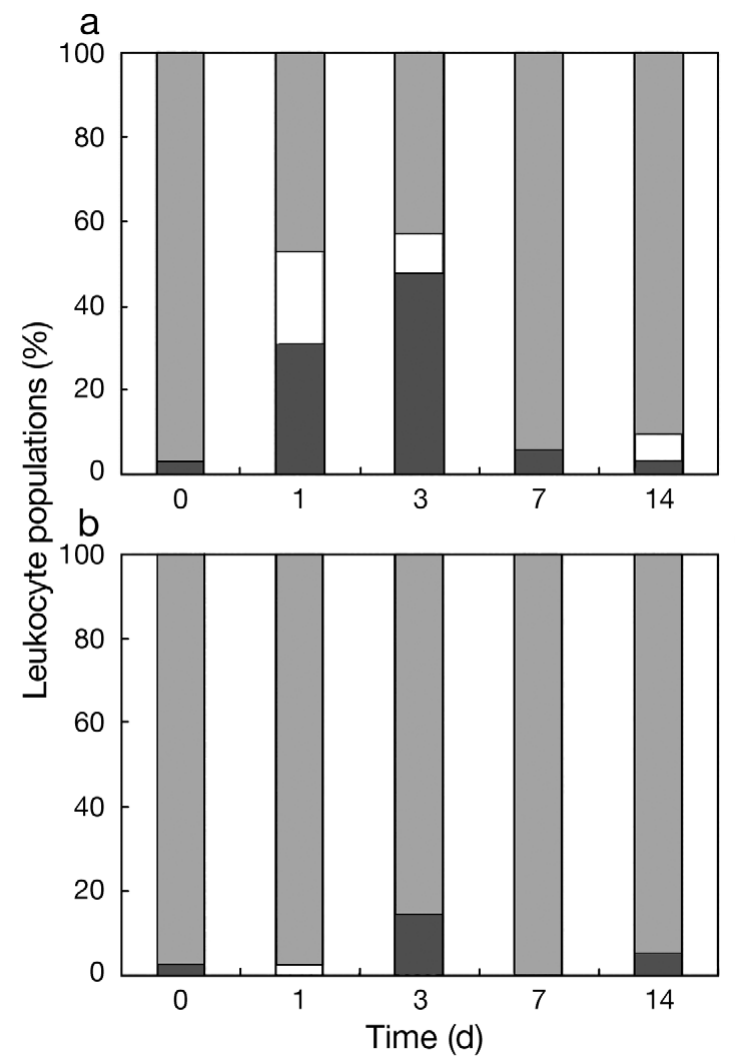

Fig. 6. Morone saxatilis. Percentage of differential leukocyte populations in response to (a) infection with Mycobacterium marinum or (b) an injection of phosphate-buffered saline (PBS). $\square=$ lymphocytes; $\square=$ monocytes; $\square$ = neutrophils 


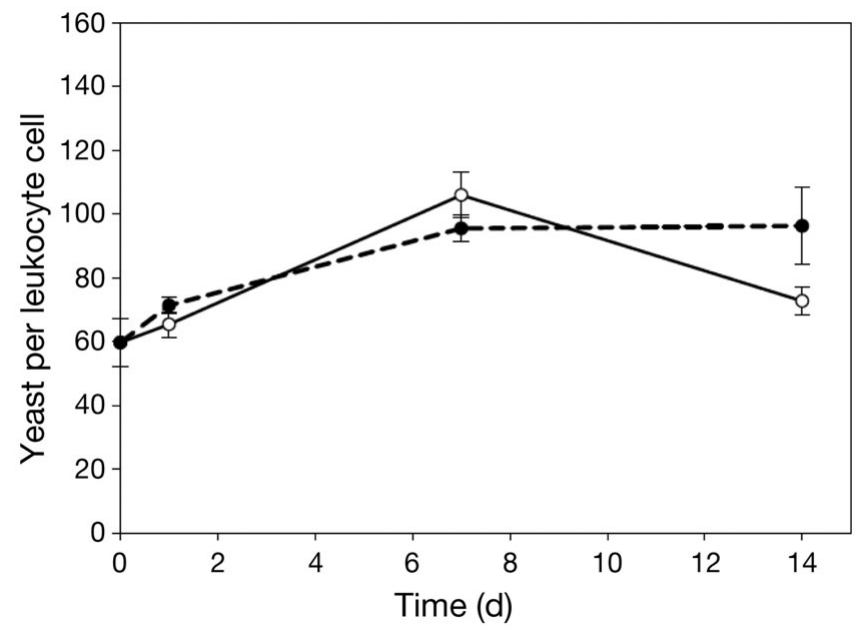

Fig. 7. Mean $( \pm$ SEM) phagocytic activity of Morone saxatilis spleen leukocytes on fluorescein isothiocyanate (FITC)labelled yeast from striped bass treated with Mycobacterium marinum (•) or phosphate-buffered saline $(\mathrm{O})$

\section{DISCUSSION}

Infection with Mycobacterium marinum results in acute or chronic disease, depending on the dose of inoculum. Injection of $10^{8}$ and $10^{9} \mathrm{CFU} \mathrm{g}^{-1}$ body weight (BW) has been shown to induce acute disease, whereas injection of $10^{2}$ and $10^{7} \mathrm{CFU} \mathrm{g}^{-1} \mathrm{BW}$ has caused chronic disease in goldfish Carassius auratus (BW $=30 \mathrm{~g}$ ) (Talaat et al. 1998). Injection of $10^{4} \mathrm{CFU} \mathrm{g}{ }^{-1} \mathrm{BW}$ showed chronic granulomatous inflammation with low mortality in previous work on sea bass (Colorni et al. 1998) and striped bass (Gauthier et al. 2003, Jacobs et al. 2009a). Striped bass Morone saxatilis experimentally infected with $M$. marinum showed large granulomas and progressive inflammation as early as 2 wk post-injection in liver, kidney and the visceral cavity (Gauthier et al. 2003). In the present study, striped bass were injected i.p. with a dose of $\sim 5.8 \times 10^{4} \mathrm{CFU} \mathrm{g}^{-1} \mathrm{BW}$ of $M$. marinum to produce chronic disease, and we investigated the immune response within 2 wk of infection in order to study the early immune response to chronic mycobacteriosis.

During challenge with Mycobacterium, host production of cytokines is essential to control mycobacterial proliferation; this results in granuloma formation. In particular, a number of studies have reported that the cytokines $I L-1 \beta$ and $T N F-\alpha$ are associated with the direction of granuloma formation, persistence of granulomas and control of mycobacterial infection in mammals (Kindler et al. 1989, Rook 1994, Law et al. 1996, Orme \& Cooper 1999, Juffermans et al. 2000, Yamada et al. 2000, Birkness et al. 2007). Inactivation of $I L-1 \alpha$ and $-\beta$ genes in double-knockout mice resulted in poor granuloma formation, and enhanced growth of mycobacteria following infection (Juffermans et al. 2000). Similarly, inactivated $T N F-\alpha$ has caused granuloma disruption with bacterial growth (Jacobs et al. 2007), while excess TNF- $\alpha$ has induced hyperinflammation with subsequent necrosis (Bekker et al. 2000, Ehlers et al. 2001).

In our study, infection with Mycobacterium marinum caused significant and rapid up-regulation of inflammatory genes in the head kidneys of striped bass Morone saxatilis. $I L-1 \beta$ and $T N F-\alpha$ were up-regulated at 3 and $7 \mathrm{dpi}$, but then returned to normal levels by $14 \mathrm{dpi}$. The enhanced production of cytokines may be a direct response to the increase in systemic bacteria (i.e. if we use bacterial counts in spleen as a marker). It is likely that the migration of monocytes to infected tissues ( 1 and 3 dpi) was initiated by chemotaxis, and the observed changes in gene expression in the kidney may be a measure of increased neutrophil and monocyte populations in the blood stream and, later on, extravasation into these tissues.

Nramp has been shown to be associated with resistance to intracellular pathogens, including Mycobacterium spp. (Vidal et al. 1993). Burge et al (2004) showed Nramp expression in Chesapeake Bay striped bass (200 g) in anterior kidney and peritoneal exudate (PE) cells, following exposure to mycobacteria. In that work, striped bass received $\sim 5000 \mathrm{CFU} \mathrm{g}^{-1}$ of $M$. marinum or $M$. shottsii (i.p.) to initiate a chronic infection. In anterior kidney, no significant expression of Nramp was observed until $15 \mathrm{~d}$ after injection, when compared to controls. At $15 \mathrm{~d}$ after injection, Nramp was greatly elevated in fish injected with $M$. marinum, but was not seen in fish injected with $M$. shottsii. On the other hand, Nramp was significantly induced in PE cells at $1 \mathrm{~d}$ after injection with $M$. marinum or $M$. shottsii when compared to controls. The authors associated rapid expression of Nramp with a higher proportion of macrophages in PE cells compared to anterior kidney, and late increases of Nramp expression in anterior kidney with trafficking of mycobacteria by PE cells. In the present study, Nramp expression of Chesapeake Bay striped bass Morone saxatilis (50 $\pm 5 \mathrm{~g}$ ) was significantly up-regulated by $3 \mathrm{dpi}$, and declined to the control level at $14 \mathrm{dpi}$. In contrast to a previous study by Burge et al (2004), quick expression of Nramp was observed in head kidney. The difference may be caused by the different doses and/or strains of $M$. marinum, or size of striped bass (200 vs. $50 \mathrm{~g}$ in the present study). The early production of Nramp again may be produced by the increased number of monocytes/ macrophages (1 to $3 \mathrm{dpi}$ ). However, the increase in bacterial counts in the spleen correspond to the downregulation of Nramp by $7 \mathrm{dpi}$. Although these changes are occurring in separate tissues, both tissues filter 
blood quickly and may involve related mechanisms whereby Nramp down-regulation allows enhanced survival and replication of $M$. marinum.

In contrast to $I L-1 \beta$ and $T N F-\alpha, T G F-\beta$ is often considered an anti-inflammatory cytokine resulting in macrophage deactivation and suppressive immunoregulation. Under physiological conditions, however, there appears to be a balance between pro-inflammatory and suppressive immunoregulation (McCartneyFrancis \& Wahl 1994). Furthermore, over- or underexpression of TGF- $\beta$ can lead to the development of pathology through the disruption of host defense mechanisms (McCartney-Francis \& Wahl 1994). Harms et al. (2003) showed that high levels of TGF- $\beta$ mRNA expression in splenic mononuclear cells were exhibited by mycobacteria-challenged striped bass. However, the function of TGF- $\beta$ in fishes is not as well known. In this study, $I L-1 \beta$ and $T N F-\alpha$ reached maximum expression after TGF- $\beta$ was down-regulated ( $7 \mathrm{dpi})$. While all 3 cytokines studied here exhibited significantly elevated expression at $3 \mathrm{dpi}$, maximum expression of the pro-inflammatory genes ( $I L-1 \beta$ and $T N F-\alpha$ ) may have lagged due to crosstalk with TGF- $\beta$ and its anti-inflammatory affects.

As pro-inflammatory mediators $I L-1 \beta$ and $T N F-\alpha$ were significantly elevated in this study, it is no surprise that changes to leukocyte populations were also observed. However, although neutrophils are normally considered to be the 'first responders' to infection, it is surprising that the highest neutrophil percentages in the blood were observed at $3 \mathrm{dpi}$, and monocytes at $1 \mathrm{dpi}$. It is possible that neutrophils migrate to sites of infection quickly, within $24 \mathrm{~h}$, considering the results of previous work, where cytokine expression was quickly and highly induced by lipopolysaccharides (LPS)/Freund's complete adjuvant-stimulation by $6 \mathrm{~h}$ in striped bass (M. D. Fast pers. obs.). Otherwise, initial elevation in monocytes may be indicative of their ability to differentiate between pathogenic and non-pathogenic mycobacteria (El-Etr et al. 2001). Martins et al. (2009) showed that increased numbers of white blood cells and lymphocytes were followed by a decreased number of monocytes at $24 \mathrm{~h}$ postinjection with Enterococcus spp. in Nile tilapia Oreochromis niloticus. However, no changes in the neutrophil and monocyte counts were observed in Nile tilapia following infection with Mycobacterium marinum (Ranzani-Paiva et al. 2004). Again, there may be species-, age- and/or inoculation-specific differences between these studies.

Phagocytosis was not observed to change significantly between infected and control fish. Dautremepuits et al. (2006) likewise did not find significant differences in phagocytosis or respiratory burst in brook trout Salvelinus fontinalis infected with another intracellular pathogen, Aeromonas salmonicida. The authors suggested that the lack of response may be due to the pathogen's ability to prevent the release of reactive oxygen species (ROS) by macrophages. In order to survive within macrophages, intracellular bacteria employ numerous mechanisms, such as: prevention of lysosomal fusion with the phagosome, and the prevention of phagolysomal acidification; moreover, in the case of Mycobacterium spp., cell wall composition can prevent permeation of cells. These intracellular survival strategies may therefore make phagocytosis measurement a less than indicative measure of host resistance and ability to kill Mycobacterium spp.

In summary, Mycobacterium marinum injected into striped bass Morone saxatilis led to an increased expression of inflammatory cytokines in the head kidney early on, with fluctuating leukocyte populations in the blood. However, this inflammatory response was either ineffective or the limited time it occurred resulted in ineffective elimination of $M$. marinum as bacterial cell counts did not peak until inflammatory responses had decreased. As expected, M. marinum was able to survive and replicate regardless of phagocytic activity in striped bass.

Acknowledgements. This work was funded through the New York State Department of Environmental Conservation, The NOAA Living Marine Resources Cooperative Science Center, and the NOAA $\backslash$ NCCOS Cooperative Oxford Laboratory. We are grateful for the assistance of J. Brush and C. Stine with laboratory assays.

\section{LITERATURE CITED}

Aronson JD (1926) Spontaneous tuberculosis in salt water fish. J Infect Dis 39:315-320

Bekker LG, Moreira AL, Bergtold A, Freeman S, Ryffel B, Kaplan G (2000) Immunopathologic effects of tumor necrosis factor alpha in murine mycobacterial infection are dose dependent. Infect Immun 68:6954-6961

Birkness KA, Guarner J, Sable SB, Tripp RA, Kellar KL, Bartlett J, Quinn FD (2007) An in vitro model of the leukocyte interactions associated with granuloma formation in Mycobacterium tuberculosis infection. Immunol Cell Biol 85:160-168

Broussard GW, Ennis DG (2007) Mycobacterium marinum produces long-term chronic infections in medaka: a new animal model for studying human tuberculosis. Comp Biochem Physiol C 145:45-54

Bruno DW, Griffiths J, Mitchell CG, Wood BP, Fletcher ZJ, Drobniewski FA, Hastings TS (1998) Pathology attributed to Mycobacterium chelonae infection among farmed and laboratory-infected Atlantic salmon Salmo salar. Dis Aquat Org 33:101-109

Burge EJ, Gauthier DT, Ottinger CA, Van Veld PA (2004) Mycobacterium-inducible Nramp in striped bass (Morone saxatilis). Infect Immun 72:1626-1636

Cardinal JL (2001) Mycobacteriosis in striped bass Morone saxatilis from Virginia waters of Chesapeake Bay. MS thesis, Virginia Institute of Marine Science, College of William and Mary, Gloucester Point, VA 
Colorni A, Avtalion R, Knibb W, Berger E, Colorni B, Timan B (1998) Histopathology of sea bass Dicentrarchus labrax experimentally infected with Mycobacterium marinum and treated with streptomycin and garlic (Allium sativum) extract. Aquaculture 160:1-17

Cosma CL, Sherman DR, Ramakrishnan L (2003) The secret lives of the pathogenic mycobacteria. Annu Rev Microbiol 57:641-676

> Dautremepuits C, Fortier M, Croisetiere S, Belhumeur P, Fournier M (2006) Modulation of juvenile brook trout Salvelinus fontinalis cellular immune system after Aeromonas salmonicida challenge. Vet Immunol Immunopathol 110:27-36

- Decostere A, Hermans K, Haesebrouck F (2004) Piscine mycobacteriosis: a literature review covering the agent and the disease it causes in fish and humans. Vet Microbiol 99:159-166

Ehlers S, Benini J, Held HD, Roeck C, Alber G, Uhlig S (2001) Alphabeta T-cell receptor-positive cells and interferongamma, but not inducible nitric oxide synthase, are critical for granuloma necrosis in a mouse model of mycobacteriainduced pulmonary immunopathology. J Exp Med 194: $1847-1859$

El-Etr SH, Yan L, Cirillo JD (2001) Fish monocytes as a model for mycobacterial host-pathogen interactions. Infect Immun 69:7310-7317

Fast MD, Johnson SC, Jones SRM (2007) Differential expression of the pro-inflammatory cytokines IL-1 $1-1$, TNF $\alpha-1$ and IL-8 in vaccinated pink (Oncorhynchus gorbuscha) and chum (Oncorhynchus keta) salmon juveniles. Fish Shellfish Immunol 22:403-407

Gauthier DT, Rhodes MW (2009) Mycobacteriosis in fish: a review. Vet J 180:33-47

Gauthier DT, Rhodes MW, Vogelbein WK, Kator H, Ottinger CA (2003) Experimental mycobacteriosis in striped bass Morone saxatilis. Dis Aquat Org 54:105-117

Gauthier DT, Latour RJ, Heisey DM, Bonzek CF, Gartland J, Burge EJ, Vogelbein WK (2008) Mycobacteriosis-associated mortality in wild striped bass (Morone saxatilis) from Chesapeake Bay. U.S.A. Ecol Appl 18:1718-1727

Harms CA, Howard KE, Wolf JC, Smith SA, KennedyStoskopf S (2003) Transforming growth factor-b response to mycobacterial infection in striped bass Morone saxatilis and hybrid tilapia Oreochromis spp. Vet Immunol Immunopathol 95:155-163

Harrell RM, Kerby JH, Minton RV (1990) Culture and propagation of striped bass and its hybrids. Striped Bass Committee, Southern Division, American Fisheries Society, Bethesda, MD

Heckert R, Elankumaran S, Milani A, Baya A (2001) Detection of a new Mycobacterium species in wild striped bass in the Chesapeake Bay. J Clin Microbiol 39:710-715

Hedrick RP, McDowell T, Groff J (1987) Mycobacteriosis in cultured striped bass from California. J Wildl Dis 22: 391-395

> Jacobs M, Togbe D, Fremond C, Samarina A and others (2007) Tumor necrosis factor is critical to control tuberculosis infection. Microbes Infect 9:623-628

> Jacobs JM, Rhodes MR, Baya A, Reimschuessel R, Townsend H, Harrell RM (2009a) Influence of nutritional state on the progression and severity of mycobacteriosis in striped bass Morone saxatilis. Dis Aquat Org 87:183-197

> Jacobs JM, Stine CB, Baya AM, Kent ML (2009b) A review of mycobacteriosis in marine fish. J Fish Dis 32:119-130

Juffermans NP, Florquin S, Camoglio L, Verbon A and others (2000) Interleukin-1 signaling is essential for host defense during murine pulmonary tuberculosis. J Infect Dis 182: 902-908

Kindler V, Sappino AP, Grau GE, Piguet PF, Vassalli P (1989) The inducing role of tumor necrosis factor in the development of bactericidal granulomas during BCG infection. Cell 56:731-740

> Law K, Weiden M, Harkin T, Tchou-Wong K, Chi C, Rom WN (1996) Increased release of interleukin-1 beta, interleukin6 , and tumor necrosis factor- $\alpha$ by bronchoalveolar cells lavaged from involved sites in pulmonary tuberculosis. Am J Respir Crit Care Med 153:799-804

Livak KJ, Schmittgen TD (2001) Analysis of relative gene expression data using real-time quantitative PCR and the $2^{-\Delta \Delta C_{\mathrm{T}}}$ method. Methods 25:402-408

Martins ML, Vieira FN, Jeronimo GT, Mourino JLP and others (2009) Leukocyte response and 14 phagocytic activity in Nile tilapia experimentally infected with Enterococcus sp. Fish Physiol Biochem 35:219-222

McCartney-Francis NL, Wahl SM (1994) Transforming growth factor- $\beta$ : a matter of life and death. J Leukoc Biol 55:401-409

Nigrelli RF, Vogel H (1963) Spontaneous tuberculosis in fishes and other cold-blooded vertebrates with special reference to Mycobacterium fortuitum Cruz from fish and human lesions. Zoologica (NY) 48:131-144

Orme IM, Cooper AM (1999) Cytokine/chemokine cascades in immunity to tuberculosis. Immunol Today 20:307-312

Overton AS, Margraf FJ, Weedon CA, Pieper LH, May EB (2003) The prevalence of mycobacterial infections in striped bass in Chesapeake Bay. Fish Manag Ecol 10: 301-308

> Polonio RE, Wolke RE, Maclean SA, Sperry JF (2000) An in vitro assay to measure phagocytosis in striped bass hybrids (Morone saxatilis $\times$ Morone chrysops). Fish Shellfish Immunol 10:405-418

Ramakrishnan L, Valdivia RH, McKerrow J, Falkow S (1997) Mycobacterium marinum causes both long-term subclinical infection and acute disease in the leopard frog (Rana pipiens). Infect Immun 65:767-773

Ranzani-Paiva MJT, Ishikawa CM, Eiras AC, Silveira VR (2004) Effects of an experimental challenge with Mycobacterium marinum on the blood parameters of Nile Tilapia, Oreochromis niloticus (Linnaeus, 1757). Braz Arch Biol Technol 47:945-953

Rook GA (1994) Macrophages and Mycobacterium tuberculosis: the key to pathogenesis. Immunol Ser 60:249-261

Talaat AM, Reimschuessel R, Wasserman SS, Trucksis M (1998) Goldfish Carassius auratus, a novel animal model for the study of Mycobacterium marinum pathogenesis. Infect Immun 66:2938-2942

Tonjum T, Welty DB, Jantzen E, Small PL (1998) Differentiation of Mycobacterium ulcerans, $M$. marinum, and $M$. haemophilum: mapping of their relationships to $M$. tuberculosis by fatty acid profile analysis, DNA-DNA hybridization, and 16S rRNA gene sequence analysis. J Clin Microbiol 36:918-925

Vidal SM, Malo D, Vogan K, Skamene E, Gros P (1993) Natural resistance to infection with intracellular parasites: isolation of a candidate for Bcg. Cell 73:469-485

Vogelbein WK, Zwerner DE, Kator H, Rhodes MW, Cardinal J (1999) Mycobacteriosis of striped bass from Chesapeake Bay. VIMS Special Scientific Report 139, Virginia Institute of Marine Science, Gloucester Point, VA

Yamada H, Mizumo S, Horai R, Iwakura Y, Sugawara I (2000) Protective role of interleukin-1 in mycobacterial infection in IL-1 alpha/beta double-knockout mice. Lab Invest 80:759-767 